【原著】

\title{
血清トリグリセライド高值の成人におけるポリフェノールを 豊富に含むハマナス花弁抽出物の血清脂質低減効果 The Serum Lipid Lowering Effect of Rugosa Rose Petal Extract Rich in Polyphenols in Adults with High Serum Triglyceride
}

\author{
山岸 喬 ${ }^{1,2}$, 高野圭司 ${ }^{1,3,}{ }^{,}$, 近藤澄夫 ${ }^{4}$ \\ Takashi YAMAGISHI ${ }^{1,2}$, Keiji TAKANO ${ }^{1,3, *}$, Sumio KONDO ${ }^{4}$ \\ ${ }^{1}$ 株式会社はるにれバイオ研究所, \\ 2 北見工業大学 \\ ${ }^{3}$ DRC 株式会社 \\ ${ }^{4}$ 医療法人健昌会 福島健康管理センター
}

\section{【要 旨】}

目的：高トリグリセライド血症は, 動脈硬化 性疾患とくに冠動脈疾患の主要なリスク因子 である. ハマナス (Rosa rugosa) 花弁抽出物 (RE) にリスク軽減効果があるか否かを検討 した.

材料・方法：血清トリグリセライド (TG) が 正常高值かまたは軽度上昇 (120～399 mg/ dL) を示す男女成人 19 名を対象とするオー プンラベル試験を実施した. 被験者には, 1 日当り RE $200 \mathrm{mg}$ を含有する試験食品を連 続 4 週間摂取させ, 介入開始前（ベースラ イン) および介入終了時 (4 週後) に血清 TG その他の血清脂質を測定し, 各測定値に ついて群内比較を行った.

結果：ベースラインと比較した場合, 血清 TG, 血清総コレステロール, および血清 non HDL-コレステロールはいずれも有意 な低下を $(P<0.05)$, 血清 LDL-コレステロ 一ルは低下傾向 $(P=0.070)$ を示した. 一方, 血清 HDL- コレステロールのレベルはほとん ど変化しなかった. 介入期間を通して試験食 品に関連する有害事象は皆無であった.

結論：RE 含有食品は TG 高値その他の脂質 異常値の改善を通して, 冠動脈疾患の発症リ スク軽減に有用性をもつことが示唆される.
【キーワード】

ハマナス，ポリフェノール，血清トリグリセ ライド, 血清コレステロール

はじめに

わが国に括いては動脈硬化性疾患の発生率およびそ れによる死亡率はいずれもきわめて高く，冠動脈疾患 (CAD) をはじめとする虚血性疾患と, 脳梗塞・脳出血 を中心とした脳血管障害と合わせた動脈硬化性疾患によ る死亡例数は全死亡例の $30 \%$ に及んでいる ${ }^{1)}$. この死 因疫学調査の結果は, 動脈硬化性疾患の予防・治療対策 の重要性を如実に物語るものである゙2.

高トリグリセライド血症は, 動脈硬化性疾患の発症に かかわる主たる要因の 1 つであり, CAD の代表的な独 立リスク因子としても働くことが欧米の研究者によって 報告されてきた ${ }^{3-7)}$. これに一致してわが国の疫学調査 からも，血清トリグリセライド (TG) 值が高いほど CAD の発症率が高くなることが明らかにされている ${ }^{8,9)}$. し たがって，高トリグリセライド血症の改善は，同じく $\mathrm{CAD}$ の主要なリスク因子として知られる高 LDL コレス テロール血症や低 HDL コレステロール血症の改善と並 んで, 国民の健康増進のらえで重要な課題となっている. これまでの多くの研究から, これらの脂質異常症の改

受理日：2015 年 2 月 17 日

* テ530-0044 大阪府大阪市北区東天満 2-10-31 第 9 田㴊ビル 3 階 Tel: 06-6882-8201 Fax: 06-6882-8202 E-mail: keiji@drc-web.co.jp 
善衫よび CAD 発症リスクの軽減には健康的な食事と適 切な運動が有効であることが知られている ${ }^{9-11)}$. 健康的 な食事としては，飽和またはトランス型脂肪酸，コレス テロールなどを制限する一方，果物・野菜・非精製穀 物・魚・低脂肪乳製品なぞを豊富にした内容の食事が国 内外で広く推奨されている 大幅に変えることは必ずしも容易でないことから，脂質 異常症改善効果をもつ様々な植物成分に多くの研究者が 関心を寄世て和り，実際に機能性食品として利用されて いるものも少なくない ${ }^{15-17)}$.

脂質異常症のなかでもとくに高トリグリセライド血症 に対する有益な効果が期待されている植物成分として知 られているものに幾つかのバラ科バラ属植物の花弁抽出 物がある。なかでも Rosa centifolia から抽出されるエラ ジタンニン類 (ellagitannins) のポリフェノール化合物は, 培養細胞を用いた in vitro の試験で TG 合成経路の最終 段階の反応を触媒するジアシルグリセロールアシルトラ ンスフェラーゼ (DGAT) を阻害すること，抢よびマウス での経口脂質負荷試験に扔いて食後 $\mathrm{TG}$ 上昇を抑制する ことが報告されている ${ }^{18)}$.

われわれは，血清 $\mathrm{TG}$ 值が基準值上限に近いかまたは 軽度上昇を示す成人被験者を対象に行った予備試験に おいて R. centifolia の類縁種である Rosa rugosa（ハマナ ス）の花弁抽出物に同様の TG 低減効果があることを見 出した ${ }^{19}$ ， そこで今回，さらに人数を増やして本試験を 企画・実施した。

\section{材料・方法}

\section{1. 試験デザインおよび倫理}

血清 TG が 120〜399 mg/dL の範囲内，すなわち正常 高值または軽度上昇を示す男女成人を対象に，RE 含有 食品の血清 TG 拈よび血清コレステロールに及湆す影響 を検討するためのオープン試験を実施した，有効性の主 要評価指標は血清 $\mathrm{TG}$, 副次評価指標は総コレステロー ル (TC), non HDL- コレステロール (non HDL-C), LDLコレステロール (LDL-C), 抢よび HDL-コレステロール (HDL-C) の各血清濃度, とした。試験プロトコールは, 医療法人健昌会 福島健康管理センタ一倫理審査委員会 によって承認された（2014 年 1 月 24 日）。試験は,「へ ルシンキ宣言（2013 年 10 月修正)」および「疫学研究 に関する倫理指針（文部科学省・厚生労働省告示，2008 年一部改正）の遵守のもとに，2014 年 1 月から同年 3 月までの期間に, 医療法人健昌会 福島健康管理セン ター（大阪市）抒よびゴゥクリニック（大阪市）に拈い て実施した。すべての被験者情報および試験記録は，プ
ライバシー保護のために無記名の ID 番号によって特定 した。

試験プロトコール違反なしに試験を完遂し, しかも試 験食品摂取率 $>80 \%$ の被験者を有効解析対象者とした。 一方，安全性の評価は，試験食品摂取に関連して発現し た有害事象（副作用）拈よび検查值の異常変動に基づい て行った. 前者については試験食品を 1 回以上摂取した 被験者全員を，後者については所定の来院日に执けるす べての検査を完了した被験者を，各々評価対象者とした．

\section{2. 被験者}

年齢が 20 歳以上, 64 歳以下で, 血清 TG が正常高值 (120〜149 mg/dL) または軽度上昇 (150〜399 mg/dL) を示 す成人 19 名を対象に試験を実施した。ただし次のいず 孔かの除外基準に抵触する場合には除外した。 (1)血清脂 質濃度に影響を及ぼす可能性のある医薬品または特定保 健用食品その他の健康食品を常用している，(2) RE を含 有する食品を毎日摂取している, (3) RE 含有食品に対し てアレルギー反応を起こすおそれがある，(4)本試験に影 響を及ぼす可能性のある薬物療法を受けている，(5)本試 験開始時に他の臨床試験に参加している，6)試験期間中 に妊娠または授乳の予定がある，(7)生活習慣アンケート の回答その他の理由から試験責任医師により被験者とし て不適当と判断された.

選択されたすべての適格被験者に対しては, 試験に参 加する前に試験内容を十分に説明し, 文書による参加同 意を取得した。試験参加に同意した被験者には，試験期 間を通して試験参加前の生活習慣を大きく逸脱するよう な運動および食生活の変更を行わないよう指示した。

\section{3. 試験食品}

試験食品には，株式会社はるにれバイオ研究所より 提供された 2 号カプセル（プルラン製）形の RE 含有食 品製品を用いた。本製品は，1 カプセル中に RE $100 \mathrm{mg}$ （同定されたポリフェノール成分としては tellimagrandin I $20 \mathrm{mg}$, tellimagrandin II $1 \mathrm{mg}$ ，ほかに rugosin A，rugosin D，打よび casurictin)，打よびポリデキストロース $100 \mathrm{mg}$ を含导. 各被験者に 1 日当り 2 カプセル（朝食 前拈よび夕食前に 1 カプセルずつ；RE としての摂取量, $200 \mathrm{mg} /$ 日） 4 週間毎日摂取させた。（乾燥花弁粉末 $1 \mathrm{~g}$ に Tellimagrandin I と Tellimagrandin II は平均 $50 \mathrm{mg}$ 含むことから，ポリフェノール分画は乾燥花弁 $0.4 \mathrm{~g}$ の 水抽出エキスに相当する)

\section{4. 有効性評価のための検査}

被験者を介入開始前抒よび 4 週間の介入期間の最終日 
（4 週後）に，何孔も午前中に来院させ，採血を行って 血清脂質濃度を測定した。被験者には，検査日の前日に は禁酒し, 夜 9 時までに食事を終光て, それ以後は水を 飲むこと以外は飲食しないこと（すなわち検査前 12 時 間以上の絶食）を指示した.

得られた血清検体を用いて TG，TC，LDL-C，non HDL-C，および HDL-C の測定を定法に従って行った. LDL-C 值については, 「動脈硬化性疾患予防ガイドライ ン 2012 年版」 ${ }^{2)}$ そ準拠して Friedewalt 方式を用い， TC 值から（HDL-C 値+1/5TG 值）を差引いて算出した. また non HDL-C 值は，TC 值から HDL-C 值を差引いて 算出した.

\section{5. 安全性評価の方法および検査}

試験責任医師は，所定の来院日における問診および試 験日誌の記載に基づいて 4 週間の介入期間中に発現した あらゆる有害事象ならびに下記の検査項目の異常变動に ついて精査し, 試験食品との関連性の有無を判定した. 評価指標として用いた検査項目は，人体計測学的検査 (身長，体重，BMI，収縮期 - 拡張期血圧，心拍数)，血 液学的検查 (赤血球数, 白血球数, 血小板数, 白血球分 画，へモグロビン，へマトクリット), 血液生化学検査 （総蛋白，アルブミン，総ビリルビン，各種肝酵素，尿 素窒素, クレアチニン, 尿酸, 血糖, 各種電解質), 抒 よび尿検査（蛋白〔定性〕，糖〔定性〕，潜血反応〔定 性]）の各項目である.

試験食品との関連性が認められたかまたは否定できな かった有害事象および検査值異常変動については，その
重篤度，発現日と持続期間，転帰，医療処置の有無・内 容などを調査し，完全に回復するまでの追跡も併せて行 らこととした.

\section{6. 統計解析}

血清脂質に関する検査值データは平均值士標準䛊差で, その他の検査值データは平均值士標準偏差で各々表示し た。すべての計測値の群内比較（ベースライン vs 4 週 後）には対応のある $\mathrm{t}$ 検定を用いた。 $\mathrm{p}$ 值 0.05 を統計 学的有意水準とした.

\section{結 果}

\section{1. 介入開始前における被験者の特徵}

適格被験者として選択された 19 名（男性 14 名，女性 5 名）全員が試験プロトコールを完遂し，脱落例は皆無 であった。各被験者の試験食品の摂取率は 92.9 100\% の範囲内であり，80\%以下の被験者は 1 例も久られなか った.これらの結果から，19名の被験者全員を有効性 ならびに安全性の評価対象者とした。

表 1 飞，被験者集団の介入開始前（ベースライン）の 時点にォける特徴を示す。いずれの人体計測学的指標に ついても計測值にかなりのばらつきがみられたものの， すべて平均値は基準值範囲内であった，血清脂質関連指 標については, 当該指標の基準值と比較して最も著しく 異なっていたのは予想通り血清 TG であり，平均值は基 準值上限よりも $10 \%$ 以上高い値を示した。 また血清 TC, 血清 LDL-C，血清 non HDL-C，㐨よび BMI の平均值が

表 1 介入開始前（ベースライン）における被験者 $(\mathrm{n}=19)$ の特徵

\begin{tabular}{|c|c|c|}
\hline 指標 & 基準值 & 計測值 ${ }^{\text {a) }}$ \\
\hline 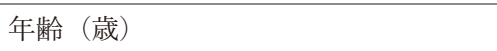 & - & $48.9 \pm 8.3$ \\
\hline 男性／女性（名／名） & - & $14 / 5$ \\
\hline 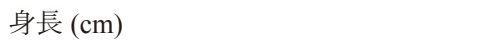 & - & $166.94 \pm 8.54$ \\
\hline 体重 (kg) & - & $72.91 \pm 12.04$ \\
\hline BMI $\left(\mathrm{kg} / \mathrm{m}^{2}\right)$ & $18.5 \sim 24.9$ & $26.04 \pm 3.05$ \\
\hline 収縮期血圧 (mmHg) & $100 \sim 139$ & $126.1 \pm 13.1$ \\
\hline 拡張期血圧 (mmHg) & $60 \sim 89$ & $78.8 \pm 13.1$ \\
\hline 心拍数（拍 / 分） & - & $67.8 \pm 10.5$ \\
\hline 空腹時血糖 (mg/dL) & $70 \sim 110$ & $85.6 \pm 7.8$ \\
\hline 血清トリグリセライド (mg/dL) & $30 \sim 149$ & $187.6 \pm 49.6$ \\
\hline 血清総コレステロール (mg/dL) & $120 \sim 219$ & $230.1 \pm 32.0$ \\
\hline 血清 non HDL- コレステロール (mg/dL) & $<170$ & $175.8 \pm 37.2$ \\
\hline 血清 LDL- コレステロール (mg/dL) & $65 \sim 139$ & $138.3 \pm 9.2$ \\
\hline \multirow[t]{2}{*}{ 血清 HDL- コレステロール (mg/dL) } & $40 \sim 85(\mathrm{M})$ & \\
\hline & $40 \sim 95(\mathrm{~F})$ & $54.2 \pm 15.4$ \\
\hline アディポネクチン $(\mu \mathrm{g} / \mathrm{mL})$ & $43.0<$ & $7.85 \pm 3.61$ \\
\hline
\end{tabular}

a) 数值（被験者数及び性別は除く）は平均值士標準偏差を表す 
表 2 血清脂質に及ぼす PE 含有食品の影響

\begin{tabular}{lccccc}
\hline \multirow{2}{*}{\multicolumn{1}{c}{ 血清脂質 }} & \multicolumn{3}{c}{ 測定值, $\mathrm{mg} / \mathrm{dL}^{\mathrm{a})}$} & 変化量, $\mathrm{mg} / \mathrm{dL}$ & $\mathrm{p}$ 值 \\
\cline { 2 - 3 } & ベースライン & 4 週後 & & (変化率) & \\
\cline { 1 - 3 } 中性脂肪 & $187.6 \pm 11.4$ & $156.9 \pm 13.8$ & $-30.7 \pm 9.9(-16.4 \pm 5.3 \%)$ & 0.006 \\
総コレステロール & $230.1 \pm 7.3$ & $215.5 \pm 6.9$ & $-14.6 \pm 4.9(-5.9 \pm 2.3 \%)$ & 0.008 \\
non HDL- コレステロール & $175.8 \pm 8.5$ & $162.6 \pm 7.9$ & $-13.3 \pm 3.8(-7.1 \pm 2.4 \%)$ & 0.003 \\
LDL- コレステロール & $138.3 \pm 9.2$ & $131.2 \pm 7.7$ & $-7.1 \pm 3.7(-3.6 \pm 2.8 \%)$ & 0.070 \\
HDL- コレステロール & $54.2 \pm 3.5$ & $52.9 \pm 2.9$ & $-1.3 \pm 2.0(-0.8 \pm 3.4 \%)$ & 0.515 \\
\hline
\end{tabular}

数值は平均值士標準䛊差を表す $(n=19)$

いずれも基準值上限近傍とやや高かった.アディポネク チンの值は，全例とも基準值範囲内であった.

\section{2. 血清脂質に及ぼす試験食品摂取の効果}

試験食品の 4 週間拱取が血清脂質にどのように影響 したかを表 2 に示す，TG，TC，non HDL-C，拈よび LDL-C の血清濃度はいずれも有意なレベルかまたはそ れに近いレベルで低下した。 なかでも最も大きく低下 したのは TG（変化量 $-14.6 \mathrm{mg} / \mathrm{dL}$, 変化率 $-16.4 \% ; \mathrm{P}=$ 0.006）であり, 続いて TC（変化量 $-14.6 \mathrm{mg} / \mathrm{dL}$, 変化 率 $-5.9 \% ; \mathrm{P}=0.008$ ), non HDL-C (変化量 $-13.3 \mathrm{ng} / \mathrm{dL}$, 変化率 $-7.1 \% ; \mathrm{P}=0.003$ ), LDL-C (変化量 $-7.1 \mathrm{mg} / \mathrm{dL}$, 変化率 $-3.6 \% ; \mathrm{P}=0.070$ ）の順に低下が著しかった。一 方，HDL-C についてはほとんど変化がみられなかった (変化量 $-1.3 \mathrm{mg} / \mathrm{dL}$, 変化率 $-0.8 \% ; \mathrm{P}=0.515$ ).

\section{3. 安全性および忍容性}

介入期間を通して試験食品の摂取を中断または中止し た被験者は 1 例もなかった。有害事象は 4 名（男性 2 名, 女性 2 名）に 1 件ずつ合計 4 件発生した（発生率, $21 \%$ ). その内訳は頭痛, 感冒様症状 (とくに頭痛), 全身掻痒 感，および軟便が各 1 件であり，いずれる試験責任医師 により試験食品との関連性はないと判定された。検査 值の異常变動に関しては, 被験者 1 名（男性）に抏い て総ビリルビン (TB) が $0.7 \mathrm{mg} / \mathrm{dL}$ （ベースライン）から $2.0 \mathrm{mg} / \mathrm{dL}$ (4 週後) への上昇が認められた. 試験責任医 師は，この TB 值の上昇は被験者の検査日前日に打ける 激しい運動（10 km の走行）によるもので試験食品とは 無関係と判定した.

\section{考 察}

本試験の結果から, 試験食品として用いた RE 含有食 品が TG 低下作用をもつ可能性がより強まった。高卜リ グリセライド血症または TG 高值が冠動脈疾患の発症 リスクを高めることは, わが国に拈ける幾つもの疫学
的調查研究 ${ }^{20-23)}$ のみならず海外の報告 ${ }^{24,25)}$ からも示され るところである。 また RE 含有食品は, TG 低減効果に 加えて，それよりは幾分軽度ながら TC， LDL-C および non HDL-C 飞対する低減効果を兼社備えていることも 判明した. LDL-C 高值拉よび non HDL-C 高值はいずれ も冠動脈疾患のリスクになることは多くの疫学的調查研 究から明らかになっている26-30). 一方, RE 含有食品は HDL-C には流とんぞ影響を与えなかった。その理由の 少なくとも 1 つは, 本試験には HDL-C 異常值を示寸被 験者が含まれていなかったことにあると考兄られる，以 上の成績は, RE 含有食品が冠動脈疾患のリスク因子と なる複数の脂質異常症を改善する効果をもつことを示し ている。したがって本食品にはそのいずれのリスクをか かえた成人に対しても幅広く有益性を発揮する可能性が あることを期待させる.

ポリフェノールは, 食品中に最も豊富に含まれる抗酸 化物質であり, 果物, 野菜, 穀類, 飲物（茶, コーヒ一, ワインなど）の重要な成分として知られる。これまで化 学的に同定された様々な植物由来ポリフェノール化合物 のなかで, 冠動脈疾患などの退行性疾患に有益な効果を 示すとしてとくに多くの注目を集めてきた化合物群につ ラボノイド類 (flavonoids) がある ${ }^{31}$. フラボノイド類の ポリフェノール化合物を豊富に含む赤ワインやブドウジ ュースが動物モデルで TG 特よび TC を低下させたとす る成績 ${ }^{32,33)}$ が報告されている一方, 同じくフラボノイド 類に属するブドウの種子由来のプロシアニジン抽出物は $\mathrm{TG}$ のみを低下させたとの報告 ${ }^{34)}$ もある。したがってフ ラボノイド類化合物が本試験の試験食品の関与成分と推 定されるェラギタンニン類のポリフェノール化合物と同 一の作用メカニズムをもつか否かは今のところ不明であ る、いずれにせよ高トリグリセライド血症は, CAD の 発症リスクになるばかりではなく, 脳梗塞のリスクも高 め $^{21,25,27,35,36)}$, さらに膵蔵炎のリスク因子として働く ${ }^{37)} こ$ とや, 肝臓内の過剩な TG 蓄積を介して非アルコール性

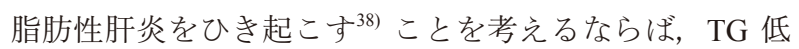
減効果の有益性はさらに拡大する可能性がある. 
RE の構成ポリフェノール成分としては, tellimagrandin I が主であり，その㴗かに tellimagrandin II, rugosin A, rugosin D といったいずれもエラギタンニ ン類のポリフェノール化合物が同定されている. Kondo らは，R. centifolia の花弁抽出物から分離したこれらの エラギタンニン類化合物が in vitro で $\mathrm{TG}$ 合成経路上の 主要酵素 DGAT を特異的に阻害することを示した ${ }^{18)}$.さ らに Shimoda らは, クルミの実由来のエラギタンニン 類（主たる推定活性成分は tellimagrandin I）が高脂肪食 摂取マウスの血清 TG を低下させること，またこの作用 は肝に拈ける脂肪酸の $\beta$ - 酸化の六進によることを報告 している ${ }^{39)}$. これらの報告からも RE 含有食品の TG 低 下作用は支持されるものと考光られる.

本試験にはいくつかの限界点がある。第 1 には，男女 被験者数が少ない（男性 14 名, 女性 5 名, 計 19 名）た めに，全員を一括した集団として取り扱い，解析を行っ た.しかし男性と女性とでは脂質代謝レベルが異なるこ とから，本来ならば別々に解析すべきである，第 2 の点 は, RE 含有ポリフェノール成分の $\mathrm{TG}$ 低下作用のメカ ニズムが不明な点である.もし推定されるようにこの作 用が $\beta$ 酸化え進によるとすれば，ケトン体の増加，さ らにはそれによるケトーシスが起こる可能性があるが, これについても検討できなかった．第 3 の点は，脂肪組 織中の TG 代謝にはホルモン感受性リパーゼの作用など の脂質代謝に関係するホルモンの影響についても考慮さ れていないことである。

したがって，今後の課題としては，REの主たる活性 成分と推定される tellimagrandin I を単離し, 上記の問題 点を配慮した試験デザインのもとに新たなヒト試験を実 施したいと考光ている.

\section{結 論}

血清トリグリセライドが正常高值もしくは高值の被 験者における TG および non HDL-C 低減効果に加えて, RE 含有食品は高い安全性を備えていることが今回の試 験結果から示された。本試験食品はこれらの効果を介し て冠動脈疾患をはじめとする動脈硬化性疾患のリスク軽 減に高い有用性をもつと考学られた。

\section{助成源}

公益財団法人北海道中小企業総合支援センター（産学 連携等研究開発支援事業)

\section{参 考 文 献}

1) 厚生労働省. 平成 23 年人口動態統計月報年計（概数）の 概況. 2014.

2) 日本動脈硬化学会編. 動脈硬化性疾患予防ガイドライン 2012 年版. 東京. 日本動脈硬化学会. 2012.

3) Le NA, Walter MF. The role of hypertriglyceridemia in atherosclerosis. Curr Atheroscler Rep 2007; 9(2): 110-115.

4) Jacobson TA, Miller M, Shaefer EJ. Hypertriglyceridemia and cardiovascular risk reduction. Clin Ther 2007; 29(5): 763-777.

5) Bersot T, Haffner S, Harris WS, et al. Hypertriglyceridemia: management of atherogenic dyslipidemia. J Fam Pract 2006; 55(7): $\mathrm{S} 1-\mathrm{S} 8$.

6) Grundy SM, Brewer HB Jr, Cleeman JI, et al. Definition of metabolic syndrome: Reports of the National Heart, Lung, and Blood Institute/American Heart Association conference on scientific issues related to definition. Circulation 2004; 109(3): 433-438.

7) Hyson D, Rutledge JC, Berglund L. Postprandial lipemia and cardiovascular disease. Curr Atheroscler Rep 2003; 5(6): 437-444.

8) Saito I, Folsom AR, Aono H, et al. Comparison of fatal coronary heart disease occurrence based on population surveys in Japan and the USA. Int J Epidemiol 2000; 29(5): 837-844.

9) Kelly RB. Diet and exercise in the management of hyperlipidemia. Am Fam Physician 2010; 81(9): 1097-1102.

10) Stampfer MJ, Hu FB, Manson JE, et al. Primary prevention of coronary heart disease in women through diet and lifestyle. $\mathrm{N}$ Engl J Med 2000; 343(1):16-22.

11) Kris-Etherton PM, Etherton TD, Carlson J, et al. Recent discoveries in inclusive food-based approaches and dietary patterns for reduction in risk for cardiovascular disease. Curr Opin Lipidol 2002; 13(4): 397-407.

12) McCullough ML, Feskanich D, Rim EB, et al. Adherence to the Dietary Guidelines for Americans and risk of major chronic disease in men. Am J Clin Nutr 2000; 72(5): 1223-1231.

13) McCullough ML, Feskanich D, Stampfer MJ, et al. Adherence to the Dietary Guidelines for Americans and risk of major chronic disease in women. Am J Clin Nutr 2000; 72(5): 1214-1222.

14) De Becker G, Ambrosioni E, Borch-Johnsen K, et al. European guidelines on cardiovascular disease and prevention in clinical practice. Atherosclerosis 2003; 171(1): 145-155.

15) Chen G, Wang $H$, Zhang $X$, et al. Nutraceuticals and functional foods in the management of hyperlipidemia. Crit Rev Food Sci Nutr 2014; 54(9): 1180-1201.

16) Chen ZY, Jiao R, Ma KY. Cholesterol-lowering nutraceuticals and functional foods. J Agric Food Chem 2008; 56(19): 8761-8773.

17) Sirtori CR, Galli C, Anderson JW, et al. Functional foods for dyslipidaemia and cardiovascular risk prevention. Nutr Res Rev 2009; 22(2): 244-261.

18) Kondo H, Hashizume K, Shibuya $Y$, et al. Identification of diacylglycerol acyltransferase inhibitors from Rosa centifolia petals. Lipids 2011; 46(8): 691-700.

19) 特開2009-102288（日本国）脂肪蓄積阻害剂.

20) Okamura T, Kokubo $Y$, Watanabe $M$, et al. A revised definition of the metabolic syndrome predicts coronary artery disease and 
ischemic stroke after adjusting for low density lipoprotein cholesterol in a 13-year cohort study of Japanese: the Suita study. Atherosclerosis 2011; 217(1): 201-206.

21) Noda H, Iso H, Saito I, et al. JPHC Study Group. The impact of the metabolic syndrome and its components on the incidence of ischemic heart disease and stroke: the Japan public health center-based study. Hypertens Res 2009; 32(4): 289-298.

22) Satoh H, Nishino T, Tomita K, et al. Fasting triglyceride is a significant risk factor for coronary artery disease in middle-aged Japanese men. Circ J 2006; 70(3): 227-231.

23) Iso $H$, Naito $Y$, Sato $S$, et al. Serum triglycerides and risk of coronary heart disease among Japanese men and women. Am J Epidemiol 2001; 153(5): 490-499.

24) Sarwar N, Danesh J, Eiriksdottir G, et al. Triglycerides and the risk of coronary heart disease: 10,158 incident cases among 262,525 participants in 29 Western prospective studies. Circulation 2007; 115(4): 450-458.

25) Patel A, Barzi F, Jamrozik K, et al. Serum triglycerides as a risk factor for cardiovascular diseases in the Asia-Pacific region. Circulation 2004; 110(17): 2678-2686.

26) Kitamura A, Noda H, Nakamura M, et al. Association between non-high-density lipoprotein cholesterol levels and the incidence of coronary heart disease among Japanese: the Circulatory Risk in Communities Study (CIRCS). J Atheroscler Thromb 2011; 18(6): 454-463.

27) Okamura T, Kokubo Y, Watanabe M, et al. Triglycerides and non-high-density lipoprotein cholesterol and the incidence of cardiovascular disease in an urban Japanese cohort: the Suita study. Atherosclerosis 2010; 209(1): 290-294.

28) Tanabe N, Iso H, Okada K, et al. Serum total and non-highdensity lipoprotein cholesterol and the risk prediction of cardiovascular events-the JALS-ECC-. Circ J 2010; 74(7): 1346-1356.

29) Noda $H$, Iso $H$, Irie F, et al. Association between non-high-density lipoprotein cholesterol concentrations and mortality from coronary heart disease among Japanese men and wome: the Ibaraki Prefectural Health Study. J Atheroscler Thromb 2010; 17(1):
$30-36$

30) Okamura T, Kokubo Y, Watanabe M, et al. Low-density lipoprotein cholesterol and non-high-density lipoprotein cholesterol and the incidence of cardiovascular disease in an urban Japanese cohort study: The Suita study. Atherosclerosis 2009; 203(2): 587592.

31) Manach C, Scalbert A, Morand C, et al. Polyphenols: food sources and bioavailability. Am J Clin Nutr 2004; 79(5): 727-747.

32) Auger C, Caporiccio B, Landrault N, et al. Red wine phenolic compounds reduce plasma lipids and apolipoprotein $\mathrm{B}$ and prevent early aortic atherosclerosis in hypercholesterolemic golden Syrian hamsters (Mesocricetus auratus). J Nutr 2002; 132(6): 1207-1213.

33) Vinson JA, Teufel K, Wu N. Red wine, dealcoholized red wine, and especially grape juice, inhibit atherosclerosis in a hamster model. Atherosclerosis 2001; 156(1): 67-72.

34) Del Bas JM, Ricketts ML, Baiges I, et al. Dietary procyanidins lower triglyceride levels signaling through the nuclear receptor small heterodimer partner. Mol Nutr Food Res 2008; 52(10): $1172-1181$.

35) Lebreuche J, Touboul PJ, Amarenco P. Plasma triglyceride levels and risk of stroke and carotid atherosclerosis: a systematic review of the epidemiological studies. Atherosclerosis 2009; 203(2): 331-345.

36) Antonios N, Angiolillo DJ, Silliman S. Hypertriglyceridemia and ischemic stroke. Eur Neurol 2008; 60(6): 269-278.

37) Yuan G, Al-Shali KZ, Hegele RA. Hypertriglyceridemia: its etiology, effects and treatment. Can Med Assoc J 2007; 176(8): 1113-1120.

38) Ferré P, Foufelle F. Hepatic steatosis: a role for de novo lipogenesis and the rranscripton factor SREBP-1c. Diabetes Obes Metab 2010; Suppl 2: 83-92.

39) Shimoda H, Tanaka J, Kikuchi M, et al. Effect of polyphenol-rich extract from walnut on diet-induced hypertriglyceridemia in mice via enhancement of fatty acid oxidation in the liver. J Agric Food Chem 2009; 57(5): 1786-1972. 


\title{
ABSTRACT \\ The Serum Lipid Lowering Effect of Rugosa Rose Petal Extract Rich in Polyphenols in Adults with High Serum Triglyceride
}

\author{
Takashi YAMAGISHI ${ }^{1,2}$, Keiji TAKANO ${ }^{1,3}$, Sumio KONDO ${ }^{4}$ \\ ${ }^{1}$ Harunire Bio Institute Ltd. \\ ${ }^{2}$ Kitami Institute of Technology \\ ${ }^{3}$ DRC Ltd. \\ ${ }^{4}$ Medical Corporation Kenshou-kai Fukushima Health Care Center
}

Objective: Hypertriglyceridemia or elevated serum triglyceride (TG) is a leading risk factor for developing atherosclerotic cardiovascular diseases. This clinical study was designed to test the potential of polyphenol-rich extract from Rosa rugosa petals (PE) for improving hypertriglyceridemia and other types of dyslipidemia.

Methods: An open-label clinical study was conducted on 19 male and female adult subjects with elevated serum TG (120-399 mg/ $\mathrm{dL}$ ), who were intervened the study diet containing (in a daily dose) $200 \mathrm{mg}$ of PE once daily for sss 4 weeks. The serum levels of TG and cholesterols were measured at baseline and week-4. The efficacy was evaluated by comparing the measurements at these two timepoints.

Results: A significant decrease $(\mathrm{P}<0.05)$ in serum TG, as well as in serum total cholesterol and non HDL-cholesterol, and a marginally significant decrease $(\mathrm{P}=0.070)$ in serum LDL-cholesterol were observed, while serum HDL-cholesterol was virtually not changed. The study diet was well tolerated without any untoward side effect.

Conclusions: The PE-containing diet appears to have benefits in improving hypertriglyceridemia and hypercholesterolemia.

Key words: Rosa rugosa, polyphenol, serum triglyceride, serum cholesterol 